\title{
Changes in Agroecosystem Structure and Function Along a Chronosequence of Taungya System in Chiapas, Mexico
}

\author{
L. Soto-Pinto ${ }^{1} \&$ C. Armijo-Florentino ${ }^{2}$ \\ ${ }^{1}$ El Colegio de la Frontera Sur (ECOSUR), Carretera Panamericana y Periférico sur s/n San Cristóbal de las \\ Casas, Chiapas, México \\ ${ }^{2}$ Universidad Autónoma Chapingo, Carretera México-Texcoco Kilómetro 38.5, Chapingo, Estado de México \\ Correspondence: Dr. L. Soto-Pinto, El Colegio de la Frontera Sur (ECOSUR).Carretera Panamericana y \\ Periférico sur s/n San Cristóbal de las Casas, Chiapas 29292, México. Tel: 52-967-674-9000. E-mail: \\ 1soto@ecosur.mx
}

Received: August 8, 2014 Accepted: August 28, 2014 Online Published: October 15, 2014

doi:10.5539/jas.v6n11p43 URL: http://dx.doi.org/10.5539/jas.v6n11p43

\begin{abstract}
The shifting cultivation system was widely used in the past; however in recent times it is no longer sustainable. In Mexico, a group of Mayan farmers established Taungya system (Ixim 'te) as alternative to shifting cultivation. The system consists of the rotational association of crops with cultivated and spontaneous timber trees. The aim was to evaluate the changes in ecological structure and functions, and economic value along a chronosequence of 2 to 13 years. Twenty farmer's plots were selected. In each plot, structure, function and economic indicators were evaluated. Along the chronosequence cultivated trees (Cedrela odorata, Swietenia macrophyla, Tabebuia rosea, Cordia alliodora and Enterolobium cyclocarpum) mixed with crops and spontaneous trees, forming a sort of diverse garden containing 75 plant species. Tree diameter, tree height, total biomass, carbon stock, timber volume, timber value and present value significantly increased along the chronosequence. Two harvests of maize and beans were obtained yearly. According to interviews in the early years maize and beans yielded about 2400 $\mathrm{kg}$ and $600 \mathrm{~kg} \mathrm{ha}^{-1}$, respectively, maize was reduced with each crop cycle at a rate of approximately $280 \mathrm{~kg} \mathrm{ha}^{-1}$ $\mathrm{yr}^{-1}$, no reductions for bean yield were reported. The number of woody species per $500 \mathrm{~m}^{2}$-sampling area showed a minimum of 4 species on the first years and a maximum of 34 species on the last years. At years 11-13 carbon aboveground stock averaged 45.4 Mg C ha ${ }^{-1}$ and stored 3.9 $\mathrm{Mg} \mathrm{C} \mathrm{ha}^{-1} \mathrm{Year}^{-1}$. The timber volume reached 110.7 $\mathrm{m}^{3} \mathrm{ha}^{-1}$; the timber value was estimated in $4261.7 \mathrm{USD} \mathrm{ha}^{-1}$ and the present value in 5665.7 USD ha ${ }^{-1}$. Most of the plots presented low levels of soil nitrogen and phosphorus. The studied system increased in complexity, productivity, carbon stocks, and economic value. However, this system may require inputs in organic matter in order to restore soil nitrogen and phosphorus.
\end{abstract}

Keywords: agroecology, agroforestry, Ch'ol, Ixim 'te, maize, Maya, milpa

\section{Introduction}

Some traditional farming systems have been robust and resilient for thousands of years such as slash-and-burn agriculture. However, these systems have been progressively displaced into marginal and unproductive lands, becoming less and less sustainable (Fischer \& Vasseur, 2000; Palm et al., 2005; Gehring et al., 2005). In shifting cultivation system, the plots are temporarily cultivated with grains and then abandoned during a period of fallow (tree phase without grains). During the fallow the natural vegetation grows, while the farmer moves to another plot to continue growing basic grains (Nations \& Nigh, 1980). The crop period is traditionally short due to a gradual decaying site quality which is overcome through a long fallow period (Ewel et al., 1981). The natural process of secondary succession occurring during the fallow helps to restore the site capacity (Brady, 1996; Quintana Ascencio et al., 1996; Sánchez, 1999; Gehring et al., 2005; Palm et al., 2005; Diemont et al., 2006, 2011; Diemont \& Martin, 2009; Schmook, 2010; Chazdon, 2014). However, a long fallow period is considered unproductive by small farmers who, having no other options, lengthen the crop period shortening the fallow. This has motivated farmers and scientist to develop agroforestry innovations such as Taungya system, in order to obtain grains along with timber products as is the case of Nigeria, Kenya, Tanzania, Burkina Faso and Ghana among other African countries (Chamshama et al., 1992; Adekunle et al., 2004; Blay et al., 2008; Kalame et al., 2011; Mullah et al., 2012). Others have maintained old traditional practices with the same multipurposes. For 
example, the Lacandon Milpa and the Telom Huasteco in Mexico (Diemont \& Martin, 2009; Cheng et al., 2011; Altieri, 2012), the Quesumgual in Honduras (Alcorn et al., 2003), the Shamba system in Kenya (Oduol, 1986), or the Tumpangsari system in Java (Wiersum, 1982). In these systems people use to tolerate, promote and cultivate trees associated with crops in a rotational scheme, involving the association of trees and crops for three to four years. The association remains as the trees grow and close the canopy. Maize, beans, cassava, potatoes, rice, squash, carrots, peas, wheat and cabbage are known to be associated between the rows of highly valued timber or fruit trees (Nair, 1993; Adekunle \& Bakare, 2004).

Taungya has been shown to be an alternative practice to shifting cultivation, as the fallow period may favor secondary succession through a process of restoration and economic value addition (Chamshama et al., 1992; Adekunle et al., 2004; Blay et al., 2008; Mullah et al., 2012). Economic and environmental benefits offered by the Taungya system contribute significantly to livelihoods increasing the net present value to more than ten times compared to systems with only trees (Kalame et al., 2011); Taungya improve survival and growth of trees (Chamshama et al., 1992; Imo, 2009), improves the nutrient uptake by maize through the effect of weed reduction (Chamshama et al., 1992; Jordan et al., 1992); the temporary abandonment of the crop period favors desirable successional effects for vegetation restoration (Quintana Ascencio et al., 1996; Gehring et al., 2005; Vieira et al., 2009; Diemont \& Martin, 2009; Chazdon, 2014); and increases the carbon sequestration capacity (Roncal-García et al., 2008; Soto-Pinto et al., 2010). In Mayan system Lacandon milpa more than 30 tree species have been recognized as potential facilitators of forest regeneration; the trees Ochroma pyramidale and Sapium lateriflorum have been demonstrated to improve soil organic matter accumulation and phosphorus concentration, respectively (Diemont et al., 2006, 2011). Ochroma pyramidale has also demonstrated its potential as facilitator in the restoration of degraded tropical forest areas (Douterlungne et al., 2008). Moreover, it is known that Taungya can reduce establishment cost since labor applied to crops can be shared with trees reducing labor costs; it increases revenues; provides food and forest products; provides employment for rural families; and in turn, can act as a buffer in reserve areas (Adekunle \& Bakare, 2004; Witcomb \& Dorward, 2009; Idol et al., 2011). Shamba system in Africa plays a leading role in the economy and provides more food and biodiversity than other systems for these areas (Oduol, 1986).

In Mexico, a group of farmers involved in the program Scolel 'te (tree growing in Mayan language) established a sort of Taungya system with the purposes of getting food, timber, other products and services, including the environmental service of carbon sequestration (De Jong et al., 1997; Soto-Pinto et al., 2010). Mayan traditional farmers usually tolerate pioneer trees in the corn fields, abandoning the land for restoration for periods between 7 and 12 years, but in this case, the innovation consisted of plant high-value-timber trees in rows, systematically planted and managed, to what we have called Ixim'te (trees with maize in tseltal language). Land and trees are owned by farmers who decided voluntarily to establish trees, select the species and the spatial and temporal arrangements. The high-value-timber tree species include the following: cedar (Cedrela odorata), mahogany (Swietenia macrophyla), "maculis" (Tabebuia rosea), "bojón" (Cordia alliodora) and "guanacastle" (Enterolobium cyclocarpum), associated with traditional "milpa" (traditional polyculture that includes maize, beans, squash, hot pepper, cassava, palms, fruit trees and other edible tubers).

Farmers have adapted the system to their own cultural and natural environment. However, it is known that the exploration on indigenous strategies is scarce (Cairns \& Garrity, 1999). This research aimed to evaluate changes in ecological structure and function, and economic benefits along a chronosequence of the Ixim'te system in Chiapas, Mexico.

\section{Materials and Methods}

\subsection{Study Area}

The study was conducted in the tropical lowland Tseltal and Ch'ol Municipalities in the Mayan area of Chiapas, Mexico, in Chilón and Salto de Agua, respectively (Figure 1). The study plots were located at an average altitude of $450 \mathrm{~m}$ above sea level, with warm-humid climate, and tropical rainforest as the natural vegetation. Soils were classified as Regosols, Leptosols, and Cambisols. Land tenure is called "ejido", a property endowed by the State, with ownership, and decision of use by the farmers. Land is mainly devoted to maize and coffee production; however livestock is becoming important in the lowlands, especially in the Ch'ol communities. 


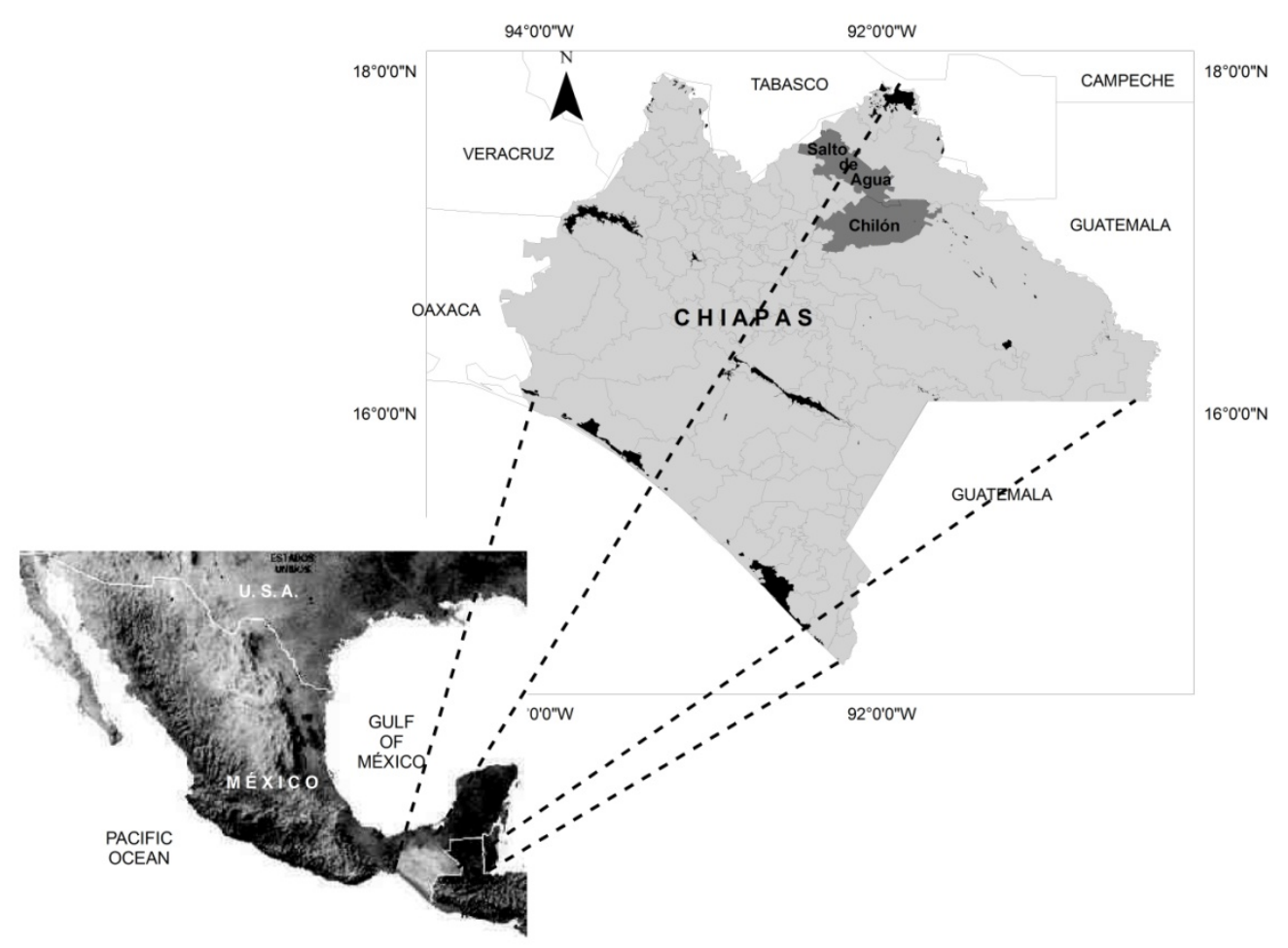

Figure 1. Study area

\subsection{Selection of Plots and Sampling}

Forty farmers established Taungya system in their plots as part of the program Scolel te of carbon sequestration. Out of these, 20 farmer's plots were selected in a chronosequence between the ages of 2 to 13 years after tree establishment. In each plot, structure and function indicators were assessed. Tree diameter, tree height, basal area, tree and sapling density were evaluated as structure indicators; biomass, species richness, species diversity, timber volume, carbon stock, and timber value were estimated as functional indicators (Begon et al., 1990; Guariguata \& Ostertag, 2001).

The plots were located in 20 to $40 \%$ slopes, with soils averaging $6.9( \pm 0.7) \mathrm{pH} ; 5.5 \%( \pm 2.7)$ organic matter; $0.27 \%( \pm 0.1)$ of total nitrogen; 8.5ppm ( \pm 5.2$)$ of phosphorus; and 364.2ppm ( \pm 192.3$)$ of potassium. Most farmers incorporate crop tillage residues to the soil to grow maize.

In each plot, a forest inventory was carried out in $500 \mathrm{~m}^{2}$-rectangles where tree height was measured with a Haga hypsometer; diameter of adult trees (trees $>0.1 \mathrm{~m}$ ) and saplings (trees $<0.1 \mathrm{~m}$ ) were measured with diametric tape and caliper, respectively. Tree and sapling species were collected and identified.

Aboveground biomass was estimated from the diameter and height of each adult and sapling trees using the following allometric formula (Chave et al., 2005):

$$
A B=\exp \left[-2.997+\ln \left(\rho D^{2} H\right)\right]
$$

Where:

$A B=$ Biomass (kg dry weight); $\rho=$ Timber density for species; $D=$ Diameter at breast height $(0.13 \mathrm{~m}) ; H=$ Height (m).

Root biomass was estimated through the following allometric formula (Cairns et al., 2000):

$$
R B=\exp [-1.0587+0.8836 \ln (A G B)]
$$

Where:

$R B=$ Total biomass of roots ( $\mathrm{kg}$ dry weight); $A G B=$ Aboveground tree and sapling biomass $\left(\mathrm{Mg} \mathrm{ha}^{-1}\right.$ of dry matter). 
Four samples of litter (freshly fallen, dry litter and humus) were collected from circles of known area. These samples were oven dried at $70{ }^{\circ} \mathrm{C}$ for $72 \mathrm{~h}$ and processed to determine carbon content according to standard laboratory procedures (IPCC, 2003).

\subsection{Soil Sampling}

In each plot a sample composed of 20 soil subsamples was taken. These were processed and analyzed in the laboratory for nitrogen by the Kjeldahl method and phosphorus by the Olsen method (CSTPA, 1980).

\subsection{Timber Volume, Timber Value and Present Value}

The timber volume was estimated using the diameter and height of all standing trees using the following formula proposed by CATIE (Tropical Education and Research Agronomic Center) for species of mountain forest $\left(\mathrm{R}^{2}=\right.$ 0.98) (Segura \& Venegas, 1999):

$$
\operatorname{Ln} V=-9.1833+2.0107(\operatorname{Ln} D)+0.7455(\operatorname{Ln} H)
$$

Where:

$V=$ Timber Volume in $\mathrm{m}^{3} ; D=$ diameter in $\mathrm{m} ; H=$ height in $\mathrm{m}$.

Timber value was estimated as harvestable wood, classifying tree stems into diametric classes, and commercial or use value classes; value for $\leq 0.1 \mathrm{~m}$-stems were assumed as firewood; value for $0.11-.029 \mathrm{~m}$ stems were assumed as poles; and value for $\geq 0.3 \mathrm{~m}$ stems were assumed as commercial timber. The value of timber was inferred from wholesale selling prices $\left(\$ 1.92\right.$ USD for $\mathrm{m}^{3}$ fuelwood, $\$ 30.0$ USD for $\mathrm{m}^{3}$ poles; $\$ 51.30$ USD for $\mathrm{m}^{3}$ pine timber, $\$ 128.37$ USD for $\mathrm{m}^{3}$ red cedar, $\$ 123.32$ USD for $\mathrm{m}^{3}$ other tropical species according to CONAFOR http://www.conafor.gob.mx:8080/documentos/docs/39/4749Reporte\%20de\%20Precios\%20de\%20Productos\%20 Forestales.pdf visited, 2014).

The present value was estimated through the following formula; fruits and other foods were qualitatively recorded:

$$
P V \text { in USD per hectare }=T V+F V+P E S
$$

Where:

$P V=$ Present value per ha in US dollars; $T V=$ Timber value; $F V=$ Food value (The price for maize and beans yielded during the first four years); $P E S=$ Payment for the ecosystem service of carbon sequestration $(\$ 1404$ USD per contract, amount payable in five expeditions during the first ten years according to Ambio Cooperative (Quechulpa Pers. Com.).

\subsection{Interviews}

Every owner of the selected plots and seven additional farmers were interviewed in order to describe the system management, land size, land tenure, inputs to the system, labor nature, labor calendar, seed types, tool kind, practices, products, species uses, and maize yields and markets, among other information about the system.

\subsection{Statistical Analysis}

Correlations between age and structure and function variables (Proc Corr) and analysis of regression (Proc Reg) between the age of establishment and the following response variables were carried out: tree diameter, tree height, basal area, tree and sapling density, biomass, species richness, timber volume, carbon stock, timber value and present value. Species frequency was produced by Proc Freq and variable tables with Proc Means with SAS (SAS, 2008).

\section{Results}

\subsection{System Description}

The Ixim 'te system is managed by farmers as a rotational low-input system, it is usually established in plots averaging 1 ha, using manual tools, local seeds and family labor. Maize is grown for self-consumption and frequently sold within the community when exceeds the amount needed by the family. Two harvest of maize and beans were obtained yearly, one first in the rainy season (summer) and the second during the winter. This last (locally named "tornamil") is grown in the winter, with residual moisture, when some associated tree species lost their leaves, allowing the association of crops (Figure 2).

The labor applied to trees consisted of: planting the seedlings on rows, weeding, pruning with the purpose to form the stem and to control the pest damage in case of attack by the borer of the Meliaceae (Hypsipila grandella); all of them were carried out with manual tools and family labor. Trees and maize shared the labor. 
After three to seven years of cropping, the plot was abandoned (tree phase without maize) in a sort of fallow. Once tree closed the canopy, some farmers cultivated coffee and edible palms under the shade of trees, using the space and shade conditions left by trees, shifting the rotational pattern to a permanent agrisilvicultural system; others cultivated grasses and introduced cattle under the trees, changing toward an agrosilvopastoral system (Figure 3).

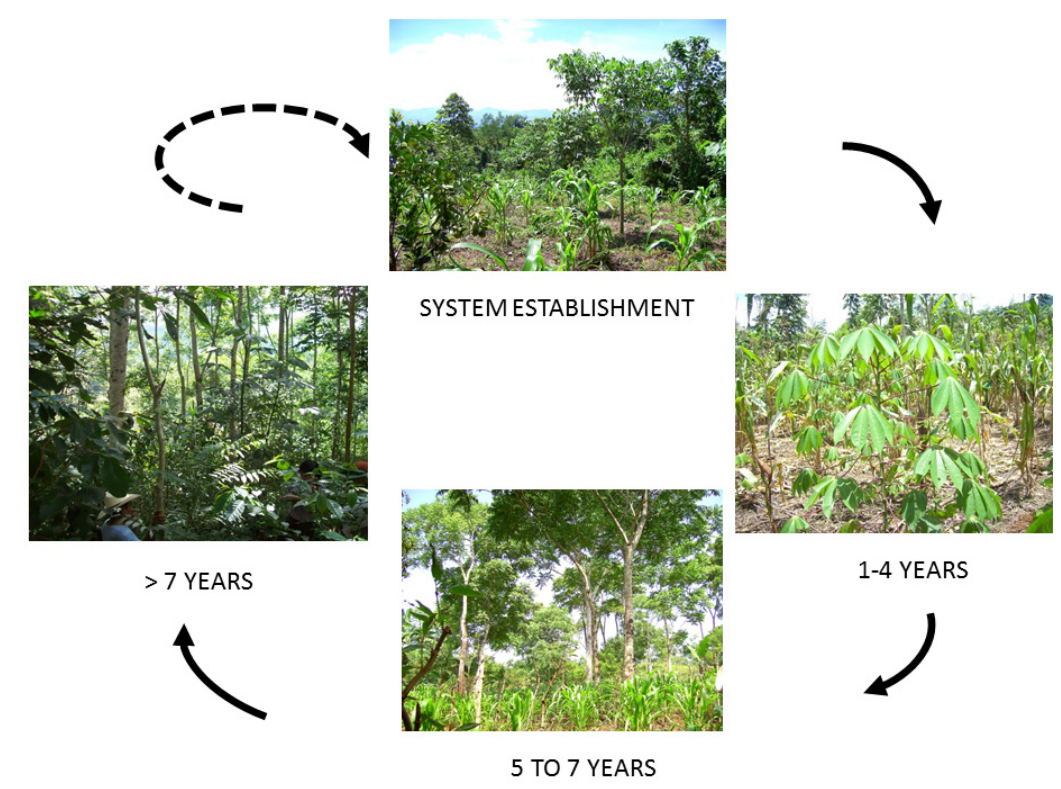

Figure 2. The cycle of Ixim'te (Taungya system) in Mayan region of Chiapas, Mexico

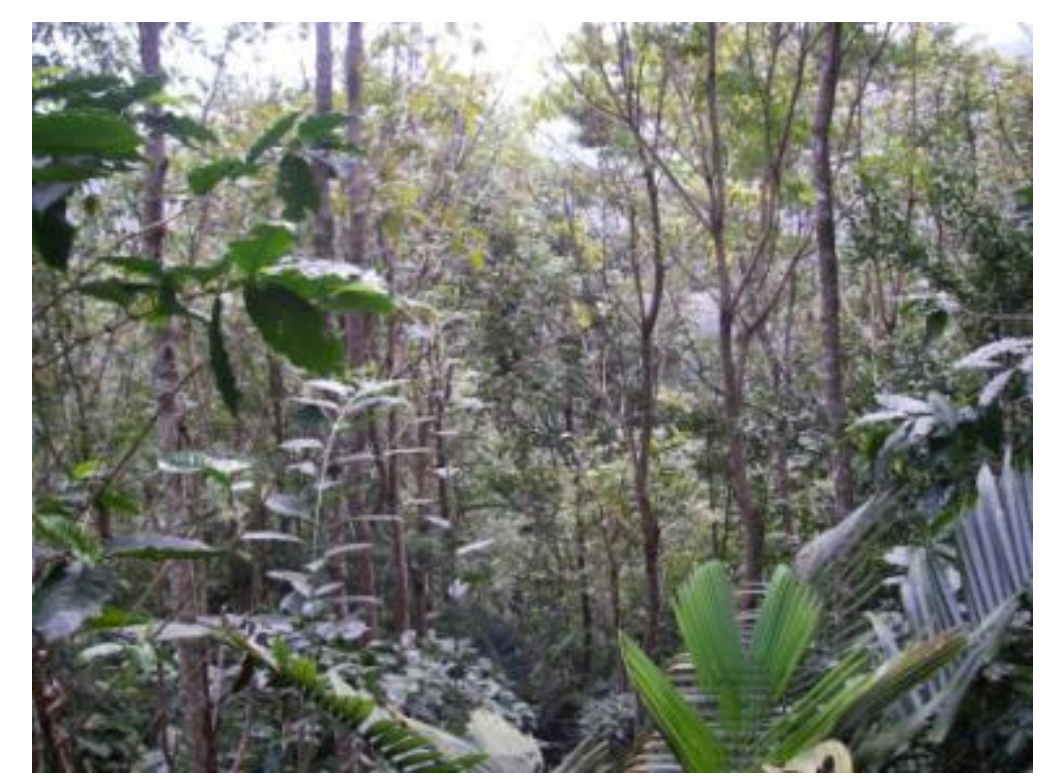

Figure 3. Thirteen-years-old Taungya system (Ixim’te) in Mayan region, Mexico

\subsection{Structure and Species Composition}

The tree species established were: cedar (Cedrela odorata), mahogany (Sweitenia macrophyla), "maculis" (Tabebuia rosea), "bojón" (Cordia alliodora) and "guanacastle" (Enterolobium cyclocarpum). Throughout the early years after establishment, cultivated trees mixed with crops and spontaneous trees, remaining associated to maize for a period varying from 3 to 7 years, forming a sort of diverse garden containing herbaceous plants, shrubs and trees. Some example of vegetables recorded were Brassica spp, Piper auritum, Capsicum spp. or 
Lycopersicum esculentum; fruit trees such as Annona muricata, Leucaena brachicarpa, Cajanus cajan, Persea americana, Musa acuminata M. sapientum, Psidium guajava, Citrus limonum, Citrus sinensis, and Pouteria sapota; tubers such as Colocasia esculenta, Xanthosoma sagittifolium, and Manihot esculenta; leguminous species such as Phaseolus spp., plants for edible flowers such as the palm Astrocaryum mexicanum or Erythrina spp. Seventy five species were recorded among herbs, shrubs, palms and trees (Table 1). These species were introduced in succession, according to farmer's knowledge about light and space requirements and deciduousness, based their experience and observations.

In the course of the first years after establishment, only saplings were recorded. Along the chronosequence tree density increased while tree saplings decreased $\left(\mathrm{P}<0.05 ; \mathrm{r}^{2}=0.57 ; \mathrm{P}<0.05 ; \mathrm{r}^{2}=-0.54\right.$ respectively) averaging on the last years of evaluation a proportion of $59.5 \%$ of saplings and $40.5 \%$ of trees (Figure 4 ).

Along the chronosequence, tree diameters and heights significantly increased $\left(\mathrm{P}<0.001 ; \mathrm{r}^{2}=0.7 ; \mathrm{P}<0.05 ; \mathrm{r}^{2}=\right.$ 0.51 respectively) (Figure 4). The maximum total height and diameter reached by trees in the oldest plantations of the study (11-13th years) averaged $11.8 \pm 2.7 \mathrm{~m}$ and $0.257 \pm 0.45 \mathrm{~m}$, respectively.
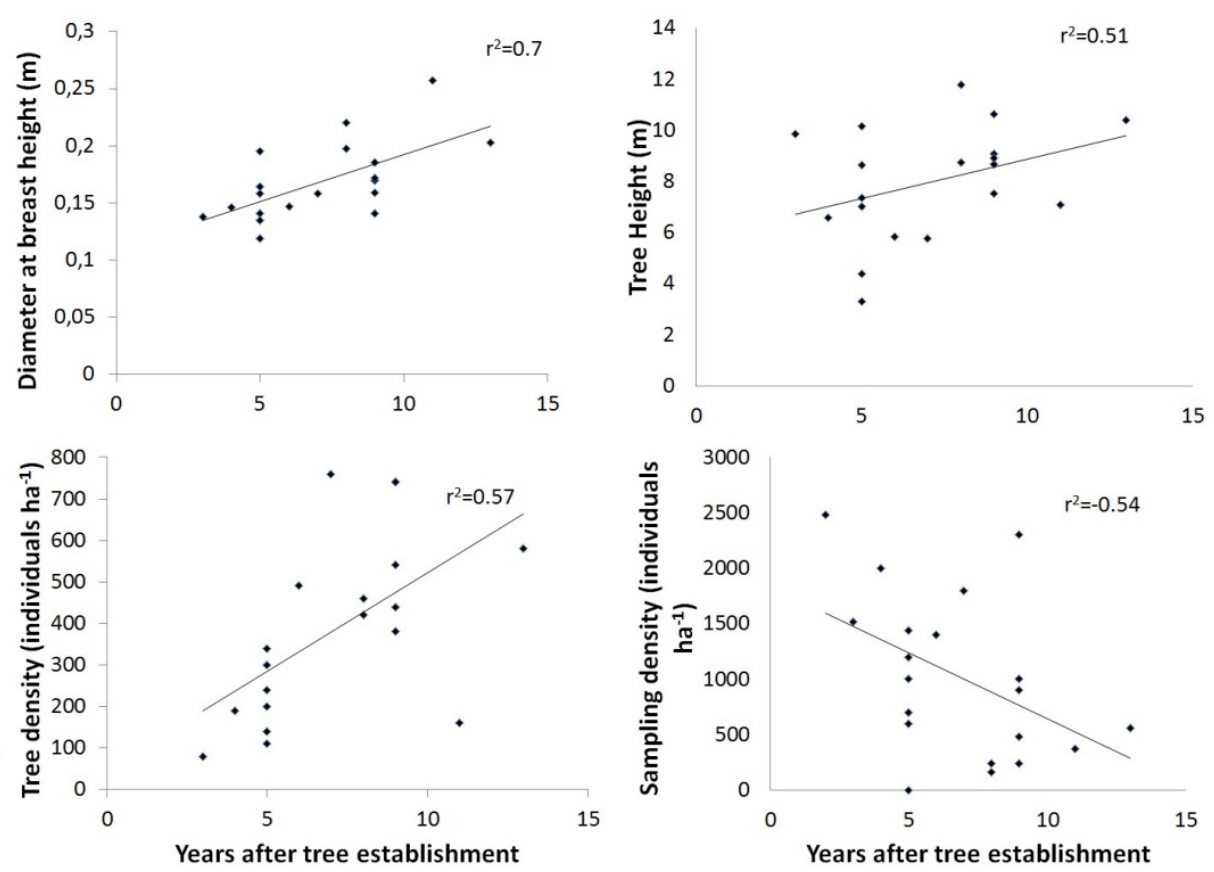

Figure 4. Relationships between age and structure indicators in Taungya plots, Mayan region of Chiapas Mexico

\subsection{Functions}

The main uses reported for the species recorded were food, forage, timber for rural construction and handicrafts, fuelwood, and medicine. Out of the total 75 species, 58 were woody species and 17 herbs (Table 1). According to the interviews, domestic and wild animals also habited the system, as well as multipurpose weeds, mushrooms, epiphytes and other plants (not accounted), showing the potential of this system to yield forest and food products.

Two harvests of maize and beans were obtained yearly. According to interviews in the early years maize and beans yielded about $2400 \mathrm{~kg}$ and $600 \mathrm{~kg} \mathrm{ha}^{-1}$, respectively (total for summer and winter harvests), maize was reduced with each crop cycle at a rate of approximately $280 \mathrm{~kg} \mathrm{ha}^{-1} \mathrm{yr}^{-1}$, no reductions for bean yield were reported.

Farmers made a continuous low-to-intermediate-intensity logging of different sizes stems, depending on their domestic needs for self-supply.

The number of woody species per $500 \mathrm{~m}^{2}$-sampling area showed a minimum of 4 species on the first years and a maximum of 34 species on the last years, this correlation was not statistically significant $\left(P>0.05 ; r^{2}=0.42\right)$ (Figure 5). 
Total biomass $\left(\mathrm{r}^{2}=0.82, \mathrm{p}<0.0001\right)$, carbon stock $\left(\mathrm{r}^{2}=0.69, \mathrm{p}<0.001\right)$, timber volume $\left(\mathrm{r}^{2}=0.78, \mathrm{p}<0.0001\right)$, timber value $\left(r^{2}=0.57, p<0.05\right)$ and present value $\left(r^{2}=0.57, p<0.05\right)$ significantly increased with age (Figure 5). The litter presented a polynomial relationship along the chronosequence with top amount between the 5 and $7^{\text {th }}$ years $\left(r^{2}=0.52\right.$ for fresh litter; $r^{2}=0.41$ for dry litter; $r^{2}=0.51$ for humus) (Figure 6). At $11-13^{\text {th }}$ years, the average total carbon stock was $45.4 \pm 1.61 \mathrm{mg} \mathrm{C} \mathrm{ha}^{-1}$, significantly increasing along the chronosequence at a rate of $3.9 \mathrm{mg} \mathrm{C} \mathrm{ha}^{-1}$ year $^{-1}$; the timber volume reached $110.7 \pm 75.63 \mathrm{~m}^{3} \mathrm{ha}^{-1}$; the timber value was estimated in $4261.7 \pm 3080.54 \mathrm{USD} \mathrm{ha}^{-1}$ and the present value in $5665.7 \pm 3080.54 \mathrm{USD} \mathrm{ha}^{-1}$. Farmers received a payment for environmental service of carbon sequestration of \$1404 USD during the first ten years of the plantation.

Considering the levels required by maize as the main crop, $60 \%$ of the soils had adequate levels of soil nitrogen and $20 \%$ of the plots had an adequate level of soil phosphorus (10 to $13 \mathrm{~kg} \mathrm{ha}^{-1}$ ).
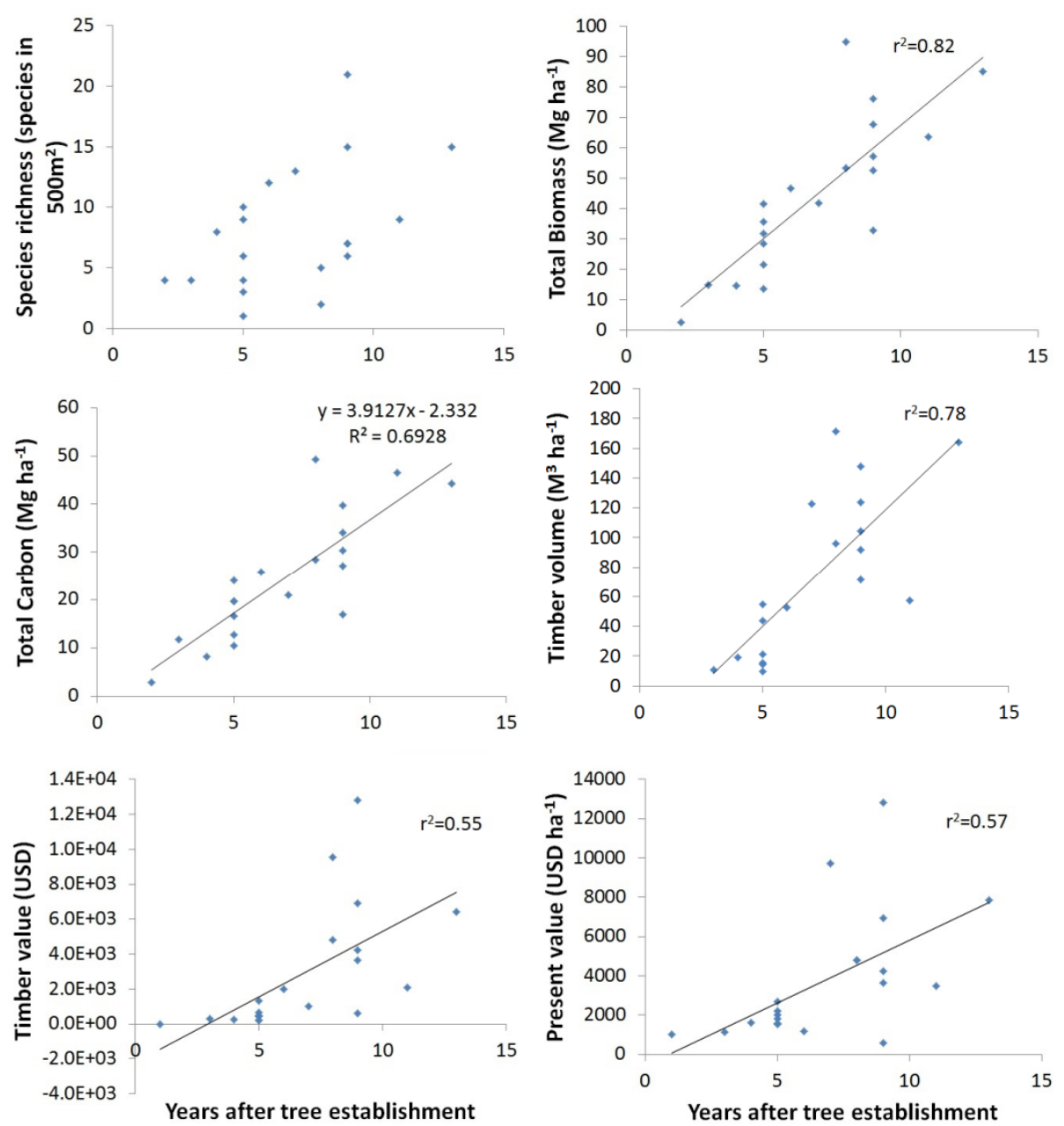

Figure 5. Relationships between age and function indicators in Taungya plots, Mayan region of Chiapas Mexico 


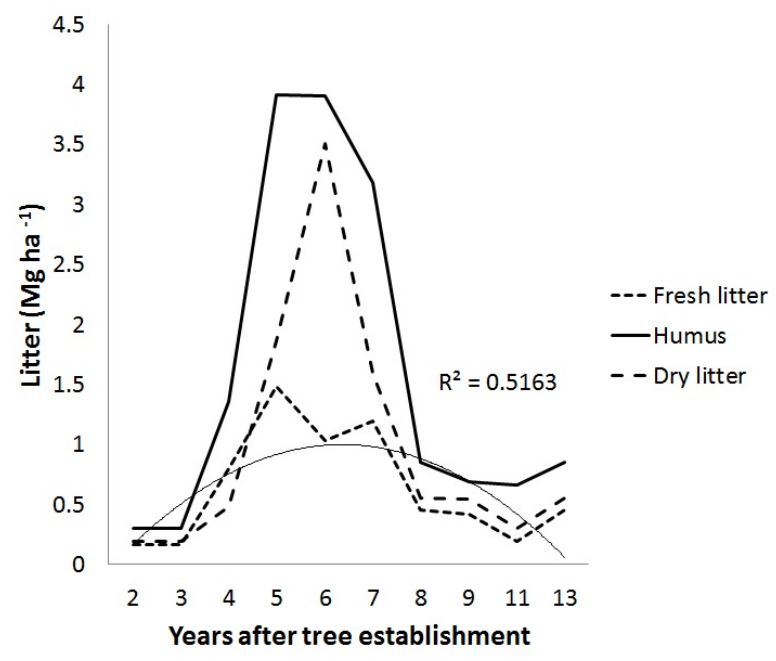

Figure 6. Polinomic relationship between age of establishment and litter in Taungya plots, Mayan region of Chiapas Mexico

Table 1. List of species, life forms and uses recorded in the Taungya system practiced by small indigenous farmers in Mayan region in Chiapas, Mexico

\begin{tabular}{|c|c|c|c|c|}
\hline Family & Scientific name & Common name & Life form & Uses \\
\hline Actinidiaceae & Saurauia villosa & Ajoj'te & 1 & 5 \\
\hline Anacardiaceae & Manguifera indica & Mango & 1 & 1 \\
\hline Annonaceae & Annona muricata & Guanábana & 1 & 1,5 \\
\hline Apiaceae & Coriandrum sativum & Cilantro & 3 & 1 \\
\hline Araceae & Colocasia esculenta & Camote & 3 & 1 \\
\hline Araceae & Xanthosoma sagittifolium & macal & 3 & 1 \\
\hline Arecaceae & Astrocaryum mexicanum & Chapay & 2 & 1,9 \\
\hline Bignonaceae & Tabebuia rosea & Maculís & 1 & 3,4 \\
\hline Bombacaceae & Ceiba petandra & Ceiba & 1 & 3 \\
\hline Boraginaceae & Cordia alliodora & Bojon & 1 & $3,4,5$ \\
\hline Brassicaceae & Brassica spp & Repollo & 3 & 1 \\
\hline Bromeliaceae & Ananas comosus & Piña & 3 & 1 \\
\hline Burseraceae & Bursera simaruba & Luluy & 1 & 5 \\
\hline Capriforliaceae & Viburnum hartwegii & Chijalap'te & 1 & 2 \\
\hline Cecropiaceae & Cecropia obtusifolia & Guarumbo & 1 & 3 \\
\hline Compositae & Eupatorium aff. sordidum & Pom'te & 1 & 5 \\
\hline Compositae & Liabum discolor & Tzuy & 2 & 5 \\
\hline Cucurbitaceae & Cucurbita pepo & Calabaza & 3 & 1 \\
\hline Cucurbitaceae & Sechium edule & Chayote & 3 & 1 \\
\hline Cupressaceae & Cuppresus & Cipres & 1 & $3,4,5$ \\
\hline Euphorbiaceae & Croton draco & chich'bat & 1 & 7 \\
\hline Euphorbiaceae & Manihot esculenta & Yuca & 3 & 1 \\
\hline Fabaceae & Cajanus cajan & Chícharo de árbol & 2 & 1,9 \\
\hline Fabaceae & Enterolobium cyclocarpum & Guanacastle & 1 & $2,3,4,5,9$ \\
\hline Fabaceae & Erythrina americana & Colorín & 1 & $1,3,9$ \\
\hline Fabaceae & Inga micheliana & Chalum & 1 & 5 \\
\hline Fabaceae & Inga pavoniana & Coquil 'te & 1 & $1,5,7$ \\
\hline Fabaceae & Inga punctata & Tzelel & 1 & $1,5,7$ \\
\hline Fabaceae & Inga radians & Machetón & 1 & $1,3,5,7$ \\
\hline Fabaceae & Leucaena brachicarpa & Guash & 1 & $1,2,3,5$ \\
\hline
\end{tabular}




\begin{tabular}{|c|c|c|c|c|}
\hline Fabaceae & Lonchocarpus sp. & shin'te & 1 & 5,7 \\
\hline Fabaceae & Phaseolus spp. & Frijol & 3 & 1 \\
\hline Fabaceae & Platymicium dimorphandrum & Hormiguillo & 1 & 3,4 \\
\hline Icacinaceae & Oecopetalum mexicanum & Caca'te & 1 & 1 \\
\hline Lauraceae & Nectandra globosa & On 'te & 1 & 5 \\
\hline Lauraceae & Persea americana & Aguacate & 1 & 1 \\
\hline Malvaceae & Pachira aquatica & Sapote de agua & 1 & 5 \\
\hline Meliaceae & Cedrela odorata & Cedro & 1 & 3,4 \\
\hline Meliaceae & Sweitenia macrophyla & Caoba & 1 & 3,4 \\
\hline Mimosaceae & Pithecolobium arboreum & Caracol & 1 & 5 \\
\hline Moraceae & Brosimum alicastrum & Ash & 1 & $2,4,5,6$ \\
\hline Musaceae & Musa acuminata & Plátano & 3 & 1 \\
\hline Musaceae & Musa sapientum & Guineo & 3 & 1 \\
\hline Myristicaceae & Virola Koschnyi & Palo de sangre & 1 & 3,4 \\
\hline Myrtaceae & Psidium guajava & Guayaba & 2 & $1,5,6$ \\
\hline Non identified & Non identified & Om 'cho & 2 & 5 \\
\hline Non identified & Non identified & Eboeshmax & 2 & 5 \\
\hline Non identified & Non identified & O'och & 2 & 5 \\
\hline Non identified & Non identified & Tzotzokil'te & 1 & 5 \\
\hline Non identified & Non identified & Yon' chuch & 1 & 5 \\
\hline Non identified & Non identified & Non identified & 1 & 5 \\
\hline Non identified & Non identified & Non identified & 1 & 5 \\
\hline Non identified & Non identified & Non identified & 1 & 5 \\
\hline Oxalidaceae & Averrhoa carambola & Carambola & 3 & 1 \\
\hline Pinaceae & Pinus & Pino & 1 & 4,5 \\
\hline Piperaceae & Piper auritum & Hierba santa & 3 & $1,6,9$ \\
\hline Poaceace & Saccharum officinarum & Caña & 3 & 1 \\
\hline Poaceace & Zea mays & Maíz & 3 & $1,2,3,9$ \\
\hline Rosaceae & Eriobotrya japonica & Nispero & 2 & 1 \\
\hline Rubiaceae & Blepharidium mexicanum & Popiste & 1 & 3,4 \\
\hline Rubiaceae & Coffea arabica & Café & 2 & 1,5 \\
\hline Rutaceae & Citrus limonum & Limón & 2 & 1 \\
\hline Rutaceae & Citrus nobilis & Mandarina & 2 & 1 \\
\hline Rutaceae & Citrus sinensis & Naranja & 2 & 1 \\
\hline Sapindaceae & Cupania dentata & Toj pos 'te & 1 & 5 \\
\hline Sapotaceae & Manilkara zapota & Chicle & 1 & $1,3,4$ \\
\hline Sapotaceae & Pouteria sapota & Zapote mamey & 1 & 1 \\
\hline Sapotáceae & Chrysophyllum mexicanum & Chijil'te & 1 & 5 \\
\hline Solanaceae & Capsicum spp. & Chile & 3 & 1 \\
\hline Solanaceae & Lycopersicum esculentum & tomate & 3 & 1 \\
\hline Sterculiaceae & Guazuma ulmifolia & Guacimo & 1 & $2,5,6$ \\
\hline Tiliaceae & Heliocarpus appendiculatus & Bat & 1 & 5,9 \\
\hline Tiliaceae & Heliocarpus donnell-smithii & Jono-han & 1 & 5,7 \\
\hline Tiliaceae & Heliocarpus spp. & Majahua o corcho & 1 & 5,7 \\
\hline Verbenaceae & Lippia myriocephala & Sac mumus & 1 & 3 \\
\hline
\end{tabular}

Use key: 1) Food; 2) Forage; 3) Construction and handicrafts; 4) Timber; 5) Fuelwood; 6) Medicine; 7) Shade; 8) Gum; 9) Other uses and services.

Life form key: 1) tree; 2) shrub; 3) herb.

\section{Discussion}

Results of the structure and function variables showed by the Taungya system called Ixim'te practiced by 
indigenous Ch'ol and Tzeltal people in Chiapas had a positive performance along the chronosequence. The structure is complex given the increment in height, diameter and positive trend of the species richness during the first 13 years from the tree establishment. Diameters increased nevertheless the continuous selective logging made by farmers, who used to remove ticker stems for domestic purposes. This selective logging seems to act as an intermediate-intensity thinning regime increasing biomass and timber volume, by increasing the illumination levels in saplings and suppressed trees of retained individuals (Guariguata \& Sáenz, 2002), which in turn increase the economic value (Norgrove \& Hausen, 2002; Piotto et al., 2003). However, the rate of value increment is lower than the rate of volume increment, probably due to the competence between cultivated and spontaneous trees. Some sites with very low timber value in the last years of evaluation were observed. It is assumed that a selective tree logging and high mortality of cultivated trees and dominance of spontaneous trees occurred along the chronosequence lowering economic value. This fact underlines the necessity of continuing planting and tolerating seedlings of high value timber species, during the fallow period, to ensure regeneration. Nevertheless, this depends on the farmer's plans, land availability and economic needs and benefits (Paladino, 2011).

The increment in adult trees and the trend to increase in species richness was also reported by others as a potential to restore site quality in a gradient from a degraded zone to secondary forest (Vieira et al., 2009; Mullah et al., 2012; Chazdon, 2014). Total density, including trees and saplings, in the 11-13-old plots was very similar to the density reported for 10-15-old secondary forests in Yucatan Mexico and in plots of earlier-stage-secondary forest in Kenya (Schmook, 2010; Mullah et al., 2012).

Moreover, productivity and ecosystem services represented by total biomass, carbon storage, timber volume, timber value and present value increased over time. Carbon increment coincides with the predictions made by $\mathrm{CO}_{2}$ fix model, for a low to intermediate intensity agroforestry systems (De Jong et al., 1997; Soto-Pinto et al., 2004) and other regional data (Roncal et al., 2008; Soto-Pinto et al., 2010). The low-to-intermediate-intensity management is based on family labour, manual tools, use of local resources and knowledge, low level of chemical inputs, and tree logging for domestic purposes; all of these criteria meet the objectives and dynamic of local indigenous livelihoods (Soto-Pinto et al., 2004). This level of management is given by the similarity between this to the traditional system, as farmers in this region usually tolerate about 200 pioneer trees per hectare in the maize crop. These trees allow rapid regeneration of vegetation when the plot is abandoned. This level of intensity allows certain multifunctionality of the systems since it provides food, timber, firewood, and other useful products to rural families and ecosystem services (Wanyeki, 1980; Kagombe \& Gitonga, 2005; Witcomb \& Dorward, 2009). Although other non-timber resources of the plantation were not studied, it is considered that to assess the compatibility between the management of timber and non-timber products is important (Guariguata et al., 2010).

The polynomial relationship of litter along the chronosequence showing a peak between the 5 to 7 th years seems to indicate the contribution of pruning debris to dead organic matter, since pruning was carried out between the 2nd and 5th year. However the quality supplied by pruning, litter and fallen debris may not be enough to satisfy the nutrient demand or to restore the site quality (Palm et al., 2014). Moreover, Tabebuia rosea, Cedrela odorata and Swietenia macrophylla have shown low litter production and slower decomposition than other tropical species due to their high lignin content, while Cordia alliodora has intermediate decomposition rate. Although the rates of decomposition of these species are known, their combination in different proportions is not as well known (Loranger et al., 2002; Scherer-Lorenzen et al., 2007).

Farmers who decide to keep the maize crop for more than three years after tree establishment grow it in winter (dry season) when the cedar, mahogany and other trees lose their leaves, this practice results in an adaptive management that allows the farmers to obtain basic grains continually. The permanence of maize for longer than three years is advantageous in terms of products; however yields are reduced due to low fertility. The low levels of nitrogen in $40 \%$ of the plots and phosphorus in most of the plots can be considered as a limitation for reforestation as has reported previously (Chazdon, 2014).

Furthermore, with Ixim 'te, the effect of trees and continuous cultivation without chemical inputs could reduce maize yields between 12 and $47 \%$ during the first four years of association, depending on tree architecture, and tree physiology and phenology (Chamshama et al., 1992; Kalame et al., 2011), distance between trees and crops (Schlönvoigt \& Beer, 2001; Kalame et al., 2011) and soil depth and management (Palm, 1995; Imo, 2009). Although leguminous trees compose the canopy of Ixim'te apparently the timber trees could be uptaking a high amount of nutrients for timber production (Palm, 1995). This limitation may be balanced using green manures as usual for crops in the Ch'ol region where people use to grow Mucuna deeringianum as green manure (Aguilar-Jimenez et al., 2011), using composts and/or using other associated plants such as Tithonia diversifolia, 
a frequent plant in the Mayan region, known as a facilitator for phosphorous absorption (Jama et al., 2000; Ikerra et al., 2006), or increasing the density of leguminous trees, but this should be further studied.

The system could be less effective with time as land availability is becoming constraint (Wiersum, 1982). Under these circumstances, the adaptations made by farmers are extremely important. Farmers have adapted the system through a process of social construction and learning, enabling the adoption of their systems. The practices adapted locally such as the management of growing winter crops acknowledging the tree deciduousness, the management of space and time with a diversity of annual and semi perennial crops based on local knowledge about successionality, the change toward permanent or silvopastoral system, and the continuous tree logging, are part of the local adaptation of Ixim te system which allows a long-term cycle with intermediate products (Kalame et al., 2011). In addition, the adaptation of the system to local conditions and joint innovation between farmers and technicians are key factors for the process of technology adoption (Shiferaw et al., 2007).

The Ixim'te system along with coffee systems, fallow vegetation, home gardens and forest patches may contribute by adding complexity to the landscape, to offer other environmental benefits including watershed protection, windbreaks, erosion control, climate amelioration, biodiversity conservation, and opportunities for restoration as proposed by other studies (Adekunle \& Bakare, 2004; Chazdon et al., 2008; Harvey et al., 2008; Vieira et al., 2009).

As observed in the region and according to interviews, Ixim 'te has three possible future scenarios; once trees close the canopy in some plots, in highest sites, may change toward a permanent use through growing coffee and native palms under the shade of trees; others, in the lowest sites may change toward a silvopastoral system including pastures and cattle under the shade of trees; and other group may rotate to maize again, though this last one has not yet occurred, at least for the period and plots studied. The establishment of coffee and palms or cattle respond to the necessity of improving productivity and economic value; however economic and the environmental trade-offs must be studied (Duchelle et al., 2012).

\section{Conclusions}

Our results suggest that Ixim'te - a sort of Taungya system managed by Mayan farmers in Chiapas increased complexity, productivity, carbon stocks, timber volume and economic value during the first 11-13 years of establishment. It works as a low to intermediate rotational system that yields timber, food, fuel, fodder, medicines and other goods and services for the rural population. This system may contribute significantly to environmental services, with an average of aboveground carbon stock of $45.4 \mathrm{mg} \mathrm{C}^{-1}$ at last years of evaluation (11-13 $3^{\text {th }}$ years), accumulating carbon at a rate of $3.9 \mathrm{mg} \mathrm{Cha}^{-1}$ year $^{-1}$; achieving an estimated potential timber volume of $110.7 \mathrm{~m}^{3}$, estimated timber harvest up to $\$ 4261.77$ US dollars, plus a yield of maize ranging between 1.6 to 2.4 ton $\mathrm{ha}^{-1}$ and a harvest of beans around 0.6 ton $\mathrm{ha}^{-1}$ for the first four years of cultivation. The Ixim 'te system has potential for producing goods and ecosystems services as it provides food, timber, firewood and other useful products to rural families, increases complexity, increase carbon stocks, timber volume and timber economic value over time. The system only applies to farmers producing goods and ecosystems services through rotational schemes. It may require inputs on organic matter and tailored managements in order to restore soil nitrogen and phosphorus. As the system could be less effective with time due to the land availability constraint, the adaptations made by farmers are extremely important in terms of learning from this system.

\section{Acknowledgements}

The authors thank the participant farmers from the Mayan areas Ch'ol and Tzeltal involved in the Scolel'te Program from the Cooperative Ambio. Manuel Anzueto Martinez, Geronimo Lopez Gomez and Miguel Cruz Mendez supported fieldwork, and Emmanuel Valencia did the map for the study area. We also thank the support of the Mexican Research Council for Science and Technology (CONACYT) grants: SEP-CONACYT 46244 and FORDECYT 116306.

\section{References}

Adekunle, V. A. J., \& Bakare, Y. (2004). Rural livelihood benefits from participation in the Taungya agroforestry system in Ondo State of Nigeria. Small-Scale Economics Management and Policy, 3(1), 131-138.

Aguilar-Jiménez, C. E., Tolón-Becerra, A., \& Lastra-Bravo, X. (2011). Effects of the maize-mucuna agroecosystem on soil properties, weed dynamics and maize yield, in traditional farming system in the Tulijá Valley, Mexico. Journal of Animal Plant Science, 12(3), 1615-1631.

Alcorn, J., Bamba, S., Masiun, I., Natalia, R., \& Royo, A. (2003). Keeping ecological resilience afloat in cross-scale turbulence: An indigenous social movement navigates change in Indonesia. In F. Berkes \& C. Folke (Eds.), Navigating social-ecological systems: building resilience for complexity and change, (pp. 
303-327). Cambridge, UK. Cambridge University Press.

Altieri, M. A. (2012). Enhancing the productivity and multifunctionality of traditional farming in Latin America. International Journal of Sustainable Development and World Ecology, 7(1), 50-61. http://dx.doi.org/10.1080/13504500009470028

Begon, M., Harper, J. L., \& Towsend, C. R. (1990). Ecology: individuals, populations and communities (Blackwell $2^{\text {nd }}$ ed.). Massachussets. USA.

Blay, D., Appiah, M., Damnyang, L., Dwomoh, F. K., Luukkanen, O., \& Pappinen, A. (2008). Involving local farmers in rehabilitation of degraded tropical forest: some lessons from Ghana. Environmental Development and Sustainability, 10, 503-578. http://dx.doi.org/10.1007/s10668-006-9077-9

Brady, N. C. (1996). Alternatives to slash-and-burn: A global imperative. Agriculture Ecosystems and Environment, 58, 3-11. http://dx.doi.org/10.1016/0167-8809(96)00650-0

Cairns, M. A., Haggerty, P. K., Alvarez, R., De Jong, B. H. J., \& Olmsted, I. (2000). Tropical Mexico`s recent land use change: A región's contributions to the global carbon cycle. Ecological Applications, 10(5), 1426-1441. http://dx.doi.org/10.1890/1051-0761(2000)010\%5B1426:TMSRLU\%5D2.0.CO;2

Cairns, M., \& Garrity D. P. (1999). Improving shifting cultivation in Southeast Asia by building on indigenous fallow management $\quad$ strategies. Agroforestry $\quad$ Systems, $\quad 47, \quad 37-48$. http://dx.doi.org/10.1023/A:1006248104991

Chamshama, S. A. O., Monela, G. C., Sekiete, K. E. A., \& Persson, A. (1992). Suitability of the Taungya system at North Kilimanjaro forest plantation, Tanzania. Agroforestry Systesms, 17, 1-11. http://dx.doi.org/10.1007/BF00122924

Chave, J., Andalo, C., Brown, S., Cairns, M., Chambers, J. Q., Eamus, D., ... Yamakura, T. (2005). Tree allometry and improved estimation of carbon stocks and balance in tropical forests. Oecologia, 145, 87-99. http://dx.doi.org/10.1007/s00442-005-0100-x

Chazdon, L. R. (2014). The promise of tropical forest regeneration in an age of deforestation. London, UK: The University of Chicago Press. http://dx.doi.org/10.7208/chicago/9780226118109.001.0001

Chazdon, L. R., Harvey, C. A., Komar, O., Griffith, D. M., Ferguson, B. F., Martínez-Ramos, M., ... Philpott, S. M. (2008). Beyond reserves: A research agenda for conserving biodiversity in human-modified tropical landscapes. Biotropica, 42(2), 142-153.

Cheng, K., Diemont, S. A. W., \& Drew, A. P. (2011). Role or tao (Belotia mexicana) in the traditional Lacandon Maya shifting cultivation ecosystem. Agroforestry Systesms, 82, 331-336. http://dx.doi.org/10.1007/s10457-011-9379-2

CSTPA. (1980). Handbook on reference methods for soil testing. Athens, Georgia. Council on Soil Testing and Plant Analysis.

De Jong, B., Tipper, R., \& Taylor, J. (1997). A framework for monitoring and evaluating carbon mitigation by farm forestry projects: example of a demonstration project in Chiapas Mexico. Mitigation and Adaptation Strategies for Global Change, 2, 231-246. http://dx.doi.org/10.1007/BF02437206

Diemont, S. A. W., Bohn, J. L., Rayome, D. D., Kelsen, S. J., \& Cheng, K. (2011). Comparisons of Mayan forest management, restoration and conservation. Forest Ecology and Management, 26, 1696-1705. http://dx.doi.org/10.1016/j.foreco.2010.11.006

Diemont, S. A. W., \& Martin, J. F. (2009). Lacandon Maya ecosystem management: Sustainable design for subsistence and environmental restoration. Ecological Applications, 19(1), $254-266$. http://dx.doi.org/10.1890/08-0176.1

Diemont, S. A. W, Martin, J. F., Levy-Tacher, S. I., Nigh, R. B., Ramirez Lopez, P., \& Golicher, J. D. (2006). Lacandon Maya forest management restoration of soil fertility using native tree species. Ecological Engineering, 28, 205-212. http://dx.doi.org/10.1016/j.ecoleng.2005.10.012

Douterlungne, D., Levy-Tacher, I., Golicherd, J., \& Roman-Dañobeytia, F. (2008). Applying indigenous knowledge to the restoration of degraded tropical rain forest clearings dominated by brackern fern. Restoration Ecology, 18(3), 322-329. http://dx.doi.org/10.1111/j.1526-100X.2008.00459.x

Duchelle, A. E., Guariguata, M. R., Less, G., Albornoz, M. A., Chavez, A., \& Melo, T. (2012). Evaluating the opportunities and limitations to multiple use of Brazil nuts and timber in Western Amazonia. Forest 
Ecology and Management, 268, 39-48. http://dx.doi.org/10.1016/j.foreco.2011.05.023

Ewel, J., Berish, C., Brown, B., Price, N., \& Raich, J. (1981). Slash with long dry seasons will have drier soils than sites burn impacts on a Costa Rican wet forest site. Ecology, 62, 816-829. http://dx.doi.org/10.2307/1937298

Fischer, A., \& Vasseur, L. (2000). The crisis of shifting cultivation practice and the promise of agroforestry: A review of the Panamian experience. Biodiversity and Conservation, 9, 739-756. http://dx.doi.org/10.1023/A:1008939425511

Gehring, C., Denich, M., \& Vlek, P. L. G. (2005). Resilience of secondary forest regrowth after slash-and-burn agriculture in central Amazonia. Journal of Tropical Ecology, 21, 519-527. http://dx.doi.org/10.1017/S0266467405002543

Guariguata, M. R., García-Fernández, C., Sheil, D., Nasi, R., Herrero-Jáuregui, C., Cronkleton, P., \& Ingram, V. (2010). Compatibility of timber and non-timber forest product management in natural tropical forests: perspectives, challenges and opportunities. Forest Ecology and Management, 259, 237-245. http://dx.doi.org/10.1016/j.foreco.2009.11.013

Guariguata, M. R., \& Ostertag, R. (2001). Neotropical secondary forest succession: Changes in structural and functional characteristics. Forest Ecology and Management, 148, 185-206. http://dx.doi.org/10.1016/S0378-1127(00)00535-1

Guariguata, M. R., \& Sáenz, G. P. (2002). Post-logging acorn production and oak regeneration in a tropical montane forest, Costa Rica. Forest Ecology and Management, 167, 285-293. http://dx.doi.org/10.1016/S0378-1127(01)00700-9

Harvey, C., Komar, O., Van Breugel, C. M., Chazdon, R., Ferguson, B. G., Finegan, B., ... Wishnie, M. (2008). Integrating agricultural landscapes with biodiversity conservation in the Mesoamerican hotspot: opportunities and an action agenda. Conservation Biology, 22(1), 8-15. http://dx.doi.org/10.1111/j.1523-1739.2007.00863.x

Idol, T., Haggar, J., \& Cox, L. (2011). Integrating agriculture, conservation and ecotourism: examples from the Field. In W. B. Campbell \& S. López Ortíz (Eds.), Issues in Agroecology - Present Status and Future Prospectus 1 (pp. 209-270). Dordrecht, The Netherlands. Springer

Ikerra, S. T., Semu, E., \& Mrema, J. P. (2006). Combining Tithonia diversifolia and Minjingu phosphate rock for improvement of $\mathrm{P}$ availability and maize grain yields on a chromic acrisol in Morogoro Tanzania. Nutrient Cycling in Agroecosystems, 76, 249-260. http://dx.doi.org/10.1007/s10705-006-9007-0

Imo, M. (2009). Interactions amongst trees and crops in Taungya systems of western Kenya. Agroforestry Systems, 76, 265-273. http://dx.doi.org/10.1007/s10457-008-9164-z

IPCC. (2003). Good Practice Guidance for Land Use, Land Use Change and Forestry (on line). National Greenhouse Gas Inventories Programme. Kanagawa, Japan. Retrieved from http://www.ipcc.ch

Jama, B., Palm, C. A., Buresh, R. J., Niang, A., Gachengo, C., Nziguheba, G., \& Mamadalo, B. (2000). Tithonia diversifolia as a green manure for soil fertility improvement in Western Kenya: A review. Agroforestry Systems, 49, 201-221. http://dx.doi.org/10.1023/A:1006339025728

Jordan, C. F., Gajeseni, J., \& Watanabe, H. (Eds.). (1992). Taungya: Forest plantations with agriculture in southern Asia. Wallingford. CAB International.

Kagombe, J. K., \& Gitonga, J. (2005). Plantation establishment in Kenya - the Shamba System Case Study. Nairobi Kenya. Kenya Forests Working Group.

Kalame, F. B., Aidoo, R., Nkem, J., Ajayie, O. C., Kanninen, M., Luukkanen, O., \& Idinoba, M. (2011). Modified Taungya system in Ghana: A win-win practice for forestry adaptation to climate change. Environmental Science and Policy, 14, 519-530. http://dx.doi.org/10.1016/j.envsci.2011.03.011

Loranger, G., Ponge, J. F., Imbert, D., \& Lavelle, P. (2002). Leaf decomposition in two semi-evergreen tropical forest: Incluence of litter quality. Biology and Fertility of Soils, 35, 247-252. http://dx.doi.org/10.1007/s00374-002-0467-3

Mullah, C. J. A., Totland, Ø., \& Klanderud, K. (2012). Recovery of plant species richness and composition in an abandoned forest settlement area in Kenya. Restoration Ecology, 20(4), 462-474. http://dx.doi.org/10.1111/j.1526-100X.2011.00810.x 
Nair, P. K. R. (1993). An introduction to agroforestry. Dordrecht. Kluwer. http://dx.doi.org/10.1007/978-94-011-1608-4

Nations, J. D. \& Nigh, R. (1980). The evolutionary potential of lacandonmaya sustained-yield tropical forest agriculture. Journal of Anthropological Ressearch, 36, 1-30.

Norgrove, L., \& Hauser, S. (2002). Measured growth and tree biomass estimates of Terminalia ivorensis in the 3 years after thinning to different stand densities in an agrisilvicultural system in Southern Cameroon. Forest Ecology and Management, 166, 261-270. http://dx.doi.org/10.1016/S0378-1127(01)00614-4

Oduol, P. A. (1986). The Shamba system: An indigenous system of food production from forest areas in Kenya. Agroforestry Systems, 4, 365-373. http://dx.doi.org/10.1007/BF00048108

Paladino, S. (2011). Tracking the fault lines of pro-poor carbon forestry. Culture, Agriculture, Food and Environment, 33(2), 117-132. http://dx.doi.org/10.1111/j.2153-9561.2011.01059.x

Palm, C. A. (1995). Contribution of agroforestry trees to nutrient requirements of intercropped plants. Agroforestry Systems, 30, 105-124. http://dx.doi.org/10.1007/BF00708916

Palm, C. A., Blanco-Canqui, H., Declerck, F., Gatere, L., \& Grace, P. (2014). Conservation agriculture and ecosystem services: an overview. Agriculture, Ecosystems and Environment, 187, 87-105. http://dx.doi.org/10.1016/j.agee.2013.10.010

Palm, C. A., Vosti, S. A., Sanchez, P. A., \& Ericksen, P. J. (2005). Slash-and-burn agriculture. The search for alternatives. New York: Columbia University Press.

Piotto, D., Montagnini, F., Ugalde, L., \& Kanninen, M. (2003). Growth and effects of thinning of mixed and pure plantations with native trees in humid tropical Costa Rica. Forest Ecology and Management, 177, 427-439. http://dx.doi.org/10.1016/S0378-1127(02)00445-0

Quintana-Ascencio, P. F., González-Espinosa M., Ramírez-Marcial, N., Dominguez-Vasquez, G., \& Martinez-Ico, M. (1996). Soil seed Banks and regeneration of tropical rain forest from Milpa fields at the Selva Lacandona, Chiapas, Mexico. Biotropica, 28(2), 192-209. http://dx.doi.org/10.2307/2389074

Roncal-García S., Soto-Pinto, L., Castellanos-Albores, J., Ramírez-Marcial, N., \& De Jong, B. (2008). Sistemas agroforestales y almacenamiento de carbono en comunidades indígenas de Chiapas, México. Interciencia, 33, 200-206.

Sánchez, P. A. (1999). Improved fallows come of age in the tropics. Agroforestry Systems, 47, 3-12. http://dx.doi.org/10.1023/A:1006287702265

Sas Institute Inc. (2008). SAS/STAT User's Guide. Release 9.2 edn. Cary N.C. SAS Institute.

Scherer-Lorenzen, M., Bonilla, J. L., \& Potvin, C. (2007). Tree species richness affects litter production and decomposition rates in a tropical biodiversity experiment. Oikos, 116, 2108-2124. http://dx.doi.org/10.1111/j.2007.0030-1299.16065.x

Schlönvoigt, A., \& Beer, J. (2001). Initial growth of pioneer timber tree species in a Taungya system in the humid lowlands of Costa Rica. Agroforestry Systems, 51, 97-108. http://dx.doi.org/10.1023/A:1010674402907

Schmook, B. (2010). Shifting maize cultivation and secondary vegetation in the Southern Yucatan: Successional forest impacts of temporal intensification. Regional Environmental Change, 10, 233-246. http://dx.doi.org/10.1007/s10113-010-0128-2

Segura, M., \& Venegas, G. (1999). Tablas de volumen comercial con corteza para encino, roble y otras especies del bosque pluvial montano de la cordillera de Talamanca, Costa Rica. Turrialba Costa Rica Centro Agronómico Tropical de Investigación y Enseñanza (CATIE).

Shiferaw, B. A., Okello, J., \& Reddy, R. V. (2009). Adoption and adaptation of natural resources management innovations in smallholder agriculture: Reflections on key lessons and best practices. Environmental Develompent and Sustainability, 11, 601-619. http://dx.doi.org/10.1007/s10668-007-9132-1

Soto-Pinto, L., Anzueto-Martinez, M., Mendoza, J., Jiménez-Ferrer, G., \& De Jong, B. (2010). Carbon sequestration through agroforestry in indigenous communities of Chiapas, Mexico. Agroforestry Systems, 78(1), 39-51. http://dx.doi.org/10.1007/s10457-009-9247-5

Soto-Pinto, L., Jimenez-Ferrer, G., Vargas-Guillen, A., De Jong, B., \& Esquivel-Bazán, E. (2004). Experiencia agroforestal para la captura de carbono en comunidades indigenas de Mexico. Revista Forestal 
Iberoamericana, 1, 44-50.

Vieira, D. L. M., Holl, K. D., \& Peneireiro, F. M. (2009). Agro-successional restoration as a strategy to facilitate $\begin{array}{lllll}\text { tropical forest } & \text { recovery. Restoration }\end{array}$ http://dx.doi.org/10.1111/j.1526-100X.2009.00570.x

Wanyeki, F. H. M. (1980). Agroforestry practices in high-potential areas of Kenya. In L. Buck (Ed.), Proceedings of the Kenya National seminar on Agroforestry. Nairobi, Kenya: ICRAF.

Wiersum, K. F. (1982). Tree gardening and Taungya on Java: Examples of agroforestry techniques in the humid tropics. Agroforestry Systems, 1, 53-70. http://dx.doi.org/10.1007/BF00044329

Witcomb, M., \& Dorward, P. (2009). An assessment of the benefits and limitations of the Shamba agroforestry system in Kenya and of management and policy requirements for its successful and sustainable reintroduction. Agroforestry Systems, 75, 261-274. http://dx.doi.org/10.1007/s10457-008-9200-z

\section{Copyrights}

Copyright for this article is retained by the author(s), with first publication rights granted to the journal.

This is an open-access article distributed under the terms and conditions of the Creative Commons Attribution license (http://creativecommons.org/licenses/by/3.0/). 